\title{
Construindo paisagens e pessoas: colonização, espaço e identidades em Cabo Verde
}

Building landscapes and people: colonization, space and identity in Cape Verde

\section{Andréa Lobo}

\section{OpenEdition}

1 Journals

Edição electrónica

URL: http://journals.openedition.org/aa/1421

DOI: 10.4000/aa.1421

ISSN: 2357-738X

Editora

Programa de Pós-Graduação em Antropologia Social (UnB)

\section{Edição impressa}

Data de publição: 1 dezembro 2015

Paginação: 121-150

ISSN: 0102-4302

\section{Refêrencia eletrónica}

Andréa Lobo, «Construindo paisagens e pessoas: colonização, espaço e identidades em Cabo Verde», Anuário Antropológico [Online], v.40 n.2 | 2015, posto online no dia 01 junho 2018, consultado o 27 abril 2021. URL: http://journals.openedition.org/aa/1421 ; DOI: https://doi.org/10.4000/aa.1421

\section{(c) (i) (9)}

Anuário Antropológico is licensed under a Creative Commons Atribuição-Uso Não-Comercial-Proibição de realização de Obras Derivadas 4.0 International. 


\section{Construindo paisagens e pessoas: colonização, espaço e identidades em Cabo Verde}

Andréa Lobo

UnB

Quando o descobridor chegou à primeira ilha nem homens nus nem mulheres nuas espreitando inocentes e medrosos detrás da vegetação nem setas venenosas vindas no ar nem gritos de alarme e de guerra ecoando pelos montes.

Havia somente as aves de rapina de garras afiadas as aves marítimas de voo largo as aves canoras assobiando inéditas melodias e a vegetação, cujas sementes vieram presas nas asas dos pássaros ao serem arrastados para cá pela fúria dos temporais.

Quando o descobridor chegou e saltou da proa do escaler varado na praia enterrando

o pé direito na areia molhada e se persignou receoso ainda e surpreso pensando n'El-Rei

Nessa hora então nessa hora inicial começou a cumprir-se este destino ainda de todos nós.

(Jorge Barbosa, 1956) 
Neste artigo, abordo o processo de construção da nação cabo-verdiana com base no discurso dos colonizadores sobre a natureza das ilhas. Os relatos se apresentam como um campo vasto e interessante, que revela a paisagem local descrita pelos olhos de quem chega e as classificaçóes e ordenaçóes oriundas desse encontro. Trata-se da fabricaçáo de um sistema classificatório que envolve, de maneira intrincada, as percepçôes culturais sobre a natureza das ilhas e a construção da personalidade do "homem cabo-verdiano". Tal processo marcará as formas como a paisagem do arquipélago é elaborada e como tal construção participa de maneira central na definição dos traços que caracterizam os habitantes das ilhas. Para dar conta desse trajeto, agrego aos relatos coloniais outras vozes: a dos intelectuais do Movimento Claridade, que contribuem com o posterior projeto político-intelectual de independência; e a dos documentos oficiais produzidos no período pós-independência, que espelham a construção do Estado nascente em uma perspectiva desenvolvimentista que agrega o adjetivo "sustentável" como símbolo de uma modernidade desejada e imaginada. ${ }^{1}$

Ao olhar para três momentos de construção de Cabo Verde, meu intuito é de observar as continuidades e descontinuidades das percepçóes sobre a natureza das ilhas. Tal como no poema de Jorge Barbosa, encaro o descobrimento e o consequente processo de colonização como um momento fundador, ou seja, entendo o discurso dos colonizadores como um referencial que orienta as concepçóes posteriores no processo de construção da nação cabo-verdiana, ora sendo reproduzido, ora sendo negado. Os atributos naturais (ou a falta deles), a localização geográfica e a insularidade são aspectos centrais nesse processo, e é para eles que direciono meu olhar.

A paisagem é entendida aqui como categoria que denota o mundo externo. Porém, não é somente o mundo que vemos, é uma construção, uma composição desse mundo, um produto social. É a consequência de uma transformação coletiva humana da natureza. É um conceito cultural que decorre de uma integração do fenômeno natural e humano que pode ser empiricamente analisado e verificado. Essa perspectiva nos permite demonstrar que a paisagem representa um modo historicamente específico de experienciar o mundo: o modo como certas classes de pessoas compreendem a si mesmas e seu mundo por intermédio de sua relação imaginada com a natureza.

Buscando explorar a noção de paisagem em uma perspectiva antropológica, na introdução à coletânea The anthropology of landscape: perspectives on place and space (2003), Hirsch afirma que, diferentemente de conceitos como ritual, troca ou história, o conceito de paisagem teria recebido pouca atenção da antropologia. Segundo o autor, na maioria das vezes ele aparece nas etnografias para se referir 
ao significado imputado pelo povo local ao seu meio cultural e físico (como uma paisagem particular se apresenta aos olhos dos seus habitantes), ou simplesmente como referência ao quadro natural que se apresenta diante do antropólogo. ${ }^{2}$

Trajano Filho (2010) traça um quadro mais complexo ao tratar dos conceitos relacionados a espaço, lugar, território e paisagem. O autor chama atenção para os desacordos sobre o lugar de tais conceitos no campo da antropologia no que se refere ao estado atual da pesquisa. Se para Hirsch (2003) a paisagem tem sido pouco problematizada na disciplina, outros autores indicariam uma vastidão de estudos sobre o espaço (Levinson, 1996). Uma primeira via de solução, indicada pelo próprio Trajano Filho (2010) ao recuperar o debate, seria a de dissociar analiticamente paisagem, espaço e lugar; e um segundo caminho, adotado por ele, é o de dar uma olhada no passado disciplinar, em que tais noçôes têm desempenhado um papel central no desenvolvimento da teoria antropológica.

Para os propósitos deste trabalho, argumento que paisagem implica modo de ver - a forma como os cabo-verdianos foram representados e representam a eles mesmos e aos outros, o mundo e suas relaçóes com ele. Entendo que o modelo analítico fundado no conceito de paisagem é particularmente interessante porque permite dar conta da forma como um lugar é carregado de significados e passa a ser pensado como o "nosso" lugar, ao qual se vincula a "nossa" existência como povo. Partilho, portanto, da perspectiva de que lugares e pessoas conectam-se por laços indissociáveis. Identidade e pertencimento estão entrelaçados aos lugares e às paisagens (físicas ou imaginadas), ambos sendo mutuamente constituídos (Lovell, 1998; Trajano Filho, 2010).

Para o caso de Cabo Verde, o campo no qual se constituem essas relaçóes fundamenta-se em valores, ideais e crenças construídos historicamente desde o momento da descoberta das ilhas, por intermédio das percepçóes e açóes que modelaram o arquipélago ao longo de cinco séculos de ocupação portuguesa e que perduram até hoje. Esse processo histórico é tanto econômico, racial, social e político quanto espacial. Trata-se, portanto, de "histórias espaciais" baseadas na experiência, que, apesar de fundamentalmente subjetiva, pode ser encontrada na poética da transformação inventiva, a qual é evidente em todas as formas de representação cultural (Foster, 1996).

\section{A “descoberta” das ilhas}

Ao terceiro dia avistamos terra, e gritando todos Terra, Terra, muito nos maravilhamos, porque não sabíamos que naquelas paragens houvesse terra alguma; e mandando subir ao mastro dois homens, descobriram duas grandes ilhas: o que sendo-nos noticiado demos graças a Deus Nosso Senhor que nos 
levava a ver cousas novas; porque bem sabíamos que destas ilhas não havia notícia alguma em Espanha. E julgando nós que elas podiam ser habitadas, para saber mais cousas e provar nossa ventura, fizemo-nos na volta de uma delas, e em pouco tempo nos achamos perto. [...] Meus homens partiram, pois, mas não acharam nada mais que terra desabitada e uma grande quantidade de pombos que se deixavam apanhar à mâo, não conhecendo ainda o que fosse o homem; e dos que mataram com paus e massas, trouxeram muitos para a caravela. Quando estiveram na montanha, houveram vista de três outras ilhas grandes, das quais náo tínhamos apercebido. [...] Ainda lhes pareceu ver da parte do Poente, muito metidas pelo mar a dentro, outras ilhas, mas não se enxergavam bem devido à sua grande distância; $e$ a estas não cuidei de ir, tanto por não perder tempo $e$ seguir minha viagem, como por julgar que eram desabitadas e selvagens como eram estas outras. Mas depois pela fama destas quatro ilhas que eu tinha encontrado, outros que aqui chegaram as foram descobrir; e acharam serem dez ilhas, entre grandes e pequenas, todas desabitadas, não encontrando nelas senão pombos e aves de estranhas sortes, e grande pescaria de peixe (Cadamosto, 1956:194; itálicos meus).

Esta história tem início em 1460, mas iria se desenvolver somente tempos depois. Como a passagem acima deixa perceber, a descoberta das ilhas de Cabo Verde não foi um fato importante em si (Silva, 1996). Indícios levam a crer que o novo espaço náo era dotado, aos olhos dos reinóis de então, de grande poder de atração. Todos os possíveis descobridores do arquipélago eram exploradores da Costa da Guiné, em busca de contatos comerciais vantajosos. Portanto, a descoberta de um arquipélago deserto, a 100 léguas a ocidente, teria provocado pouco interesse. A insularidade, o despovoamento e a ocidentalidade são apresentados como atributos desqualificantes. A descrição de Cadamosto ${ }^{3}$ demonstra esse desinteresse e a desvalorização do espaço descoberto quando afirma ter avistado mais duas ilhas às quais não chegou a ir "por julgar que eram desabitadas e selvagens como eram estas duas outras".

Em um primeiro momento, a posição geográfica das ilhas, isto é, a distância que as separava do reino é apresentada como um fator negativo, um entrave nas tentativas de colonização. Essa posição não era estratégica pelo fato de as ilhas estarem situadas muito ao sul do mundo conhecido pelos portugueses. Outro ponto seria sua localização numa zona quente e seca, não podendo proporcionar o cultivo de produtos mediterrâneos, como o trigo, a cevada e a azeitona. A sahelidade de Santiago (a primeira ilha descoberta) se expressava tanto pelo regime das secas como pela composição do ambiente, formando um quadro muito distinto daquele que os portugueses haviam conhecido nos arquipélagos atlânticos até então. 
Até 1466, a ilha de Santiago, como as demais, encontrava-se escassamente habitada. Porém, foi nesse ano que o quadro começou a mudar, mediante a apresentação de um documento que tratava da permissão dos fixados em Santiago de comercializarem com as sociedades ribeirinhas do continente africano e com a Europa. A prática desse comércio era considerada ilícita senão mediante expressa autorização régia. Nesse sentido, o referido documento constituía um trunfo para os povoadores de Santiago, uma vez que estar em Santiago representava adquirir o direito do exercício do comércio euro-africano. Essa prerrogativa jurídica tornou a ilha um lugar atrativo e um polo de imigração, reclassificando sua posição como estratégica.

Além dos privilégios outorgados, a própria localização geográfica passou a ser um fator de reforço da atratividade da ilha, cuja posiçâo se tornou ideal e segura para a residência dos comerciantes que eram impossibilitados de se fixar nos mercados entre os rios Senegal e da Serra Leoa por razóes climáticas, sanitárias e de segurança. Santiago era um lugar simultaneamente próximo da costa africana, constituindo uma base avançada de rápidas e seguras incursóes comerciais; e suficientemente longe do continente para ser, por si só, uma barreira contra as açóes ofensivas dos poderes africanos.

A posição era privilegiada também para os missionários incumbidos da evangelizaçáo dos povos do continente e dos escravos trazidos para Santiago a fim de serem exportados para os mercados de trabalho nas Américas, assim como daqueles destinados ao povoamento das ilhas e seu desenvolvimento econômico. O objetivo era a difusão do cristianismo e o escambo. Como as ilhas não eram habitadas e não apresentavam quaisquer marcas de ocupação humana, os recémchegados puseram-se a trabalhar, tentando construir a paisagem, a flora e a fauna, que até então só tinham sido afetadas pelas forças da natureza.

A montagem de uma infraestrutura em Santiago fez da ilha uma grande fornecedora de água potável, mantimentos e alimentos, frutos, carne salgada, tartaruga, permitindo que os navios efetivassem longas e morosas viagens para o sul da África. Cabe lembrar que, durante vários anos, não houve outro ponto seguro de reabastecimento da navegaçáo na costa africana. Sendo assim, a criação dessas instalaçôes e a fixação de europeus, apoiados na máo de obra escrava, permitiram o ingresso do arquipélago nas correntes de comércio mundial no findar do século XV. No mesmo período, a economia começou a se diversificar e, além do tráfico de escravos para o sul da Espanha, Algarve, Ilha da Madeira, Antilhas e Américas, bem como da exportação de urzela para França, Itália e Inglaterra, iniciou-se o cultivo da cana-de-açúcar para a fabricação de aguardente, destinada ao comércio na costa africana, e de algum açúcar mascavo para consumo local e exportação. 
No começo do século XVI, vemos crescer a figura dos lançados: reinóis cristãos, judeus e cristáos-novos - e mestiços que se instalaram nos portos africanos a comerciar sem licença régia e considerados perdidos para a cristandade e para a civilizaçáo europeia. Eles tomaram conta do comércio costeiro, entre os rios de Senegal e o norte da Serra Leoa atual. ${ }^{4}$ De acordo com os relatos, os negócios na costa deram lucros muito mais substanciais a Cabo Verde do que o próprio tráfico de escravos. Este durou de 1486 a 1647, data em que passou a ser permitido o despacho dos navios dos rios da Guiné diretamente aos portos de destino, sem a fiscalização da Alfândega da Ribeira Grande.

Por outro lado, enquanto os concorrentes não se organizavam, era na ilha que iam sendo depositados os escravos trazidos da costa com o objetivo de serem preparados e exportados. Apesar de essa atividade ter começado muito cedo, foi nos anos de 1600 que se foi tendo melhor conhecimento dos métodos e processos adotados na chamada ladinização dos escravos, sendo esta mais uma atividade importante que insere o arquipélago no contexto de expansão colonial portuguesa. As construçôes em torno dos significados do arquipélago nesse contexto é o que explorarei a seguir.

\section{A paisagem das ilhas aos olhos do colonizador}

As primeiras descriçôes sobre o espaço natural do arquipélago são as dos descobridores das ilhas. Além desses e não de forma diferente, os viajantes e mercadores da costa africana deixaram observaçôes, ainda que parciais e lacônicas, acerca da natureza do Cabo Verde insular. Referem-se apenas às ilhas do Sudeste (Boa Vista, Maio e Santiago), por serem mais próximas ao continente, e são visôes de "quem passa", registrando aqui e ali algum traço que lhes parece mais digno de menção.

Neumann (1995:17), contextualizando a questão da paisagem na situação colonial africana em geral, afirma que "as terras e povos africanos desafiaram a visão familiar de natureza e paisagem dos recém-chegados colonizadores europeus", os quais eram obrigados a negociar entre dois mundos: a metrópole perdida e esse outro ainda não codificado. Sendo assim, o colonizador construiria o que o autor chama de "paisagem de transiçáa" - a ponte entre as convençóes da metrópole e a realidade colonial, onde a desvalorização ou a valorização do novo se dá em comparação ao que ficou para trás.

No caso de Cabo Verde, o contraste entre os dois mundos se expressa pelas noções de abundância-prosperidade e escassez-pobreza associadas ora à colônia, ora à metrópole, mas sempre em oposiçáo. Para os colonizadores e viajantes dos séculos XV e XVI, esses foram séculos marcados pela decadência total da 
agricultura em Portugal, expressa em relatos como o de Padre Baltasar Barreira: "por ser em grande número a pobreza do Reino, principalmente nos campos, onde na verdade tudo é pobreza” (apud Brásio, 1968).

À paisagem de não prosperidade, de crise e de pobreza na qual se encontrava Portugal, é contraposto um cenário de abundância e de prosperidade constantemente enfatizado nos relatos e documentos de viajantes, cenário que contrasta com uma Europa afundada num processo de transiçáo culminada com a escassez de cereais e uma profunda crise nos campos. Diante desse contexto, enquadrava-se uma visão otimista que vislumbrava, em novas terras, uma possibilidade de vida. A abundância revela a imagem altamente positiva das novas terras, um convite a sua ocupação. A natureza é tida como dadivosa nesta "parte meridional do mundo", uma fertilidade e uma exuberância tais que parecem prometer prosperidade e abundância para aqueles que dela se ocuparem e retirarem seus recursos. $\mathrm{O}$ arquipélago é caracterizado, então, não como um lugar real, mas como uma construção ideal, uma paisagem imaginada pouco coincidente com o Cabo Verde que conhecemos, que tem na aridez sua mais profunda síntese.

O trecho que deu início à seção anterior é um bom exemplo dos relatos que marcam esse primeiro momento. Ao escrever sobre sua navegação, Cadamosto trata da descoberta das ilhas de Cabo Verde, conferindo a si mesmo o status de descobridor daquelas terras desabitadas e selvagens, não encontrando nelas "senão pombos e aves de estranhas sortes, e grandes pescarias de peixes" (1956:194). Em sua breve descrição das ilhas encontradas, temos algo de abundância e fartura, inclusive de água. Cadamosto continua fazendo referência à abundância de tartarugas enormes e saborosas e à táo grande quantidade de peixes "como nunca haviam visto antes, tấo grandes e saborosos que eram”. O rio é descrito como grande e de muito boa água. À ilha a que se refere foi dado o nome de Boa Vista, por ter sido a primeira terra vista por aquelas partes. ${ }^{5}$

A partir dos anos de 1600, as descriçóes começaram a sinalizar para uma transição das percepçóes sobre as ilhas. Entretanto, em um primeiro momento, o cenário ainda tinha como marca descritiva a positividade, com destaque para a fertilidade. Relatos, sobretudo, de missionários faziam referência às ribeiras e aos vales amenos que havia em seu interior, onde "a ribeira donde bebemos me parecem tão frescos como os mais frescos desse reino” (Brásio, 1968:43). O autor refere-se também aos ventos fortes, às árvores e plantas, que

fazem amenos estes vales, aos coqueiros, palmeiras, parreiras, marmeleiros, figueiras, limoeiros e todas as demais árvores de espinho. Tudo o que querem 
plantar e semear dá muito bem, até trigo e os demais legumes e hortaliças. As frutas que tenho visto - melóes, uvas, figos, marmelos, laranjas, etc — são as melhores da Europa (Brásio, 1968:43). ${ }^{6}$

Entretanto, opondo-se às terras férteis, o clima começou a ser descrito como doentio, referência inexistente nos relatos anteriores. Nesse cenário vemos, nos anos de 1610-1611, a fome ser relatada por Padre Barreira:

Estes anos com tão grande fome por não chover, que sendo antes abundantíssimas de mantimentos e havendo dela seca para outras partes, foi necessário que desse Reino lhe viesse a sustentação. E porque este mantimento era somente para os que tinham para o comprar por preços mui excessivos, a mais gente morria como de peste pelas ervas e sevandilhas que comiam [...]. Desta fome táo extraordinária se seguiram muitos insultos e roubos porque andavam os homens em alcatéias, e nem havia casa de campo que não escalassem, nem gado que não matassem, nem caminhantes que não salteassem pelos caminhos. A isto se juntou uma praga de moscas nunca vista, porque foi geral em toda a ilha e consumia o gado que escapava aos salteadores, chupando-lhe o sangue ... (apud Brásio, 1968:465).

Para além do clima hostil, que compromete a fertilidade da terra, começa a se configurar no discurso desses atores uma relação direta entre penúria material e penúria espiritual, e entre pobreza da terra e pobreza dos homens. Mais tarde, veremos que essa relação voltará a ser feita pelos reinóis, referindo-se aos negros da terra e escravos como um aspecto negativo e passivo da paisagem. Por agora, é necessário lembrar que essa é uma fase de decadência da economia e sociedade escravocratas em Cabo Verde, e que é nesse período que começam os relatos das primeiras fomes e secas com seu impacto desestruturador na sociedade. ${ }^{7}$ As secas têm, portanto, um forte impacto negativo sobre a estrutura escravocrata, porque sua ocorrência se conjuga com os dados conjunturais desse período histórico - a incapacidade estrutural em importar alimentos e vender escravos.

Para dar conta desses processos, é preciso avançar no tempo e chegar ao século XVIII. É graças ao historiador cabo-verdiano Antônio Carreira que podemos conhecer esse período, pois foi ele quem reuniu documentos que retratam a situação de Cabo Verde à época. O arquipélago parece ter sofrido crises de várias ordens nesse século; entre elas, as frequentes estiagens causadoras de fomes e de mortandades e a depressão econômica acentuada devido à queda quase vertical do tráfico de escravos. A tendência atrás referida não cessou de agravarse. As fomes se repetiam ciclicamente, corroendo e degenerando a estrutura produtiva. Seus efeitos acumulados iam subvertendo a sociedade escravocrata, modificando-a irreversivelmente, cada fome representando a aceleração das tendências de desagregação. 
Carreira (1985) publicou um manuscrito que é mais correntemente conhecido como "Anônimo de 1784", com a designação de "Notícia corográfica e cronológica do bispado de Cabo Verde" — o anônimo refere-se às fomes dos anos de 1773, 1774 e 1775, em que "a maior parte da plebe padeceu na Ilha de Santiago". Porém, nos anos chuvosos a terra era "abundantíssima de alimentos". "Não faltando a chuva ao menos três meses, que são os de agosto, setembro e outubro, que é o tempo em que costuma chover neste clima, se produz muito milho grosso sem mais trabalho do que fazer umas covinhas em que possam caber dois ou três grãos de milho, e enterrá-lo com a ponta do pé" (1985:23). Essas descriçóes continuavam a retratar as ilhas, principalmente Santiago, como localidades de bons pastos, ricas em vales com muitas ribeiras de água doce corrente, com abundância de hortaliças, "imensidades de ananazes (abacaxi) e bananas". A ilha de São Nicolau é descrita como a mais fértil, porque produz milho, feijão, abóbora, banana, algodão e vinho.

Em contraposição a esse cenário de abundância encontram-se os anos de fome e seca, em que a população de muitas ilhas foi reduzida à metade, bem como suas criaçóes de gado e burro e suas plantaçóes. De 1773 a 1776, parece ter ocorrido uma das fomes mais terríveis que assolaram as ilhas. Durante esse período, grande parte da população escrava sucumbiu à morte. As marcas dessa fome foram tão intensas que se torna difícil chamar de escravocrata à sociedade que dela sobreviveu. É o caso de Santiago, onde "antes da esterilidade havia cerca de 25.000 almas; agora terá menos da metade", e São Nicolau, onde com a "esterilidade dos anos de 1773,1774 e 1775 morreram com fome quase todos os moradores desta freguesia, e hoje haverá ao muito nela até 50 casais, e nem aqueles moradores se podem acrescentar porque são pobres demais" (apud Carreira, 1985:18).

Somam-se a isso as caracterizaçóes da população local como preguiçosa, mal instruída, possuída pelo vício da ociosidade e da sensualidade, especialmente as mulheres negras:

cada um não semeia senão para comer aquele ano, sustentam-se de milho que artificialmente reduzem a farinha, de que fazem cuscus e xarém [...]. Como se conhecem favorecidos do clima náo há ali um só indivíduo que se sujeite a servir, em nada jamais são úteis a ninguém, pois nem a si mesmo o são. [...] Este povo cheio de preguiça e inaçáo, nascido em um país abundante de gados e mantimentos, cuidam muito pouco da sua criação, concorrendo desta sorte para a sua mesma indigência, padecendo ainda mais em tempo em que, por falta de chuvas, são aquelas terras tão infrutíferas que tem sentido várias vezes a mais horrível necessidade, sendo a última a do ano de 72 até 74 em que pereceram 14.000 almas (apud Carreira, 1983:177). 
O texto não é assinado e encontra-se numa coletânea de "Documentos para a História das Ilhas de Cabo Verde e 'Rios da Guiné': séculos XVII e XVIII" (Carreira, 1983). Tem-se aqui um claro exemplo da tendência de relacionar aspectos do comportamento moral e físico degradante (indolência e preguiça) a condiçôes climáticas, à qualidade do ar, à ausência de regulação social. Indo além, o autor culpa o povo das ilhas pelas condiçôes degradantes e a alta mortandade que a seca lhes impóe.

Dando continuidade à relação determinística entre a natureza das ilhas e a dos homens, chegamos ao século XIX, período em que a descrição física de Cabo Verde passou a ser mais organizada e mais técnica. Os relatos apresentados se concentraram na fertilidade e nos frutos de enorme variedade oferecidos pela terra, e detalharam as características dos terrenos, do clima e da quantidade de água em cada ilha. $\mathrm{O}$ terreno foi descrito como quase totalmente seco e árido, mas fertilíssimo naquelas áreas onde não faltava água. $\mathrm{O}$ clima era geralmente quente. Na época das chuvas, "é doentio quanto mais estas são abundantes, tanto a doença é mais geral e perigosa”.

A indolência era tida como natural e associada aos habitantes de todos os climas quentes, onde a natureza tem poucas precisóes. Em meados desse século, um oficial português comentava que essas regiôes longínquas e de climas pouco salubres influíam não só na vida nativa, mas na dos europeus que lá habitavam por muito tempo. Influenciados pelo ambiente local, eles perderiam o caráter e a bondade e tornar-se-iam aborrecidos e bárbaros (Valdez, 1864). De forma crescente, a miséria e a pobreza passavam a ser dissociadas da natureza do clima, sendo atribuídas à indolência, à preguiça e aos maus hábitos de higiene dos nativos.

No Boletim Oficial no 43, de 1872, foram dadas notícias de Santo Antão:

fazer desta uma terra regular e higiênica é impossível. Os habitantes em sua maioria não são mendigos porque o sustento do povo na província, exceto nos anos de crises alimentares, é duma sem igual barateza, mas são realmente pobríssimos. Contar com eles para qualquer coisa é viver de enganos. O que poderá, pois, esperar-se de tâo pobre gente? (GOVERNO GERAL DA PROVÍNCIA DE CABO VERDE, 1872:238).

A caracterização do nativo como parte da paisagem não é novidade nos relatos coloniais. É comum vermos as penúrias do clima, da paisagem e da natureza local serem associadas à penúria dos homens da terra, e a pobreza da terra ser relacionada à pobreza espiritual, integrando o nativo à paisagem natural. $\mathrm{O}$ que observamos em Cabo Verde, ao focar nos dados aqui analisados, insere-se, portanto, em um contexto mais amplo: o de uma espécie de associação cíclica entre o caráter 
humano e o ambiente geográfico. O homem das ilhas surgiu como produto de atributos negativos associados ao clima (árido, hostil e insalubre). Entretanto, esse homem foi convertido em produtor de uma paisagem degradada, na medida em que não extraía da terra fértil seus frutos. No decorrer dos séculos que marcam a ocupação colonial do arquipélago, a culpa se deslocou do clima doentio para o homem indolente, preguiçoso e de moral duvidosa.

Nesse percurso, porém, o discurso sobre a natureza das ilhas guardou uma continuidade. A perspectiva de uma paisagem maravilhosa marcada pela abundância, pela diversidade de frutos e animais e por alguma fartura de água presente nos primeiros textos náo desapareceu de todo no decorrer dos relatos. Ela, primeiro, ganhou a forma da fertilidade, de uma terra em que "se plantando tudo dá", e posteriormente assumiu um tom mais realista, quando incorporou as noçóes de aridez, da qualidade dos terrenos, da dificuldade em obter água potável. Entretanto, potencialmente a terra é fértil e dadivosa. Não fosse o clima hostil e a indolência dos homens, as ilhas seriam "abundantíssimas de mantimentos" (apud Brásio, 1968:465).

Nas próximas seçôes, veremos que as construçôes sobre as ilhas e seus habitantes seriam retomadas por atores que parecem se contrapor às imagens coloniais, percebidas como externas ao arquipélago e permeadas por relaçóes de poder que devem ser contestadas e revertidas. Perguntar não só pelas rupturas, mas também pelas continuidades será fundamental para percebermos a complexidade e as sutilezas desse diálogo, que, ao fim e ao cabo, é central para a construção dessa sociedade.

\section{Finca-pé na txon}

Reza a lenda que Deus, depois de construir o mundo, cansado, colocou um pé na África Negra e outro na Europa, sacudiu as santas mãos e caíram dez bocados de barro. Sem se aperceber, criou as dez ilhas de Cabo

Verde e, desta forma, marcou o destino do povo do arquipélago. Esquecidas pelo Senhor, o tempo sucedeu ao tempo e as ilhas foram achadas desertas pelos portugueses e habitada. Povos africanos e europeus ali, em perfeita simbiose, se miscigenaram e da metamorfose resultou outro homem, o cabo-verdiano.

(Baltasar Lopes da Silva, 1947) 
O movimento em torno da revista Claridade é considerado pelos críticos o maior acontecimento do panorama literário cabo-verdiano. Conforme sinaliza Monteiro (2013), no início do século XX se desenvolveu uma literatura sui generis nos países africanos de língua portuguesa e, em Cabo Verde, essa construção deu-se com o advento da Claridade. As condiçóes para seu surgimento tiveram origem, de um lado, em fatores locais que geravam forte descontentamento no arquipélago e, de outro, na articulação de uma elite letrada local com um ambiente internacional efervescente (Movimento Futurista na Europa, Modernismo no Brasil, movimento da Negritude na França).

As ilhas mergulhadas na miséria das secas e das fomes, o índice de mortalidade elevado e a situação de abandono teriam estimulado o nascimento de um movimento de insatisfação e denúncia dos problemas sociais diante do descaso da metrópole. Claridade, Revista de Arte e Letras foi lançada em 1936, na cidade de Mindelo, Ilha de São Vicente, e os principais dinamizadores do grupo eram Baltasar Lopes, Manuel Lopes e Jorge Barbosa. Sob a liderança do primeiro e o lema de finca-pé na txon ("fincar os pés na terra"), o grupo assumiu uma atitude crítica perante a realidade cabo-verdiana e passou a produzir uma literatura que se dedicava a refletir sobre a realidade do arquipélago, o caráter e o sofrimento do povo cabo-verdiano, assumindo uma perspectiva de literatura como função social. ${ }^{8}$

Um dos temas centrais desenvolvidos na Claridade refere-se ao espaço, à paisagem e ao clima em Cabo Verde e sua participação na definição dos traços que caracterizam os habitantes das ilhas. O clima certamente pode ser considerado um fator de grande influência na formação de Cabo Verde, que esteve sujeito a frequentes e prolongadas estiagens ao longo de sua história. A seca e as crises de fome condicionaram, em larga medida, a trajetória socioeconômica do país, deixando sua marca na dura realidade vivenciada pela população do arquipélago, obrigada a enfrentar uma série de dificuldades para sobreviver.

Carreira (1984) realizou um estudo no qual apresentou vários registros e relatos das grandes secas ocorridas em Cabo Verde nos primeiros anos do século XX. São publicações de jornais, notícias de rádio e cartas de governantes portugueses que descrevem o cenário cabo-verdiano durante os grandes períodos de estiagens desde os fins do século XIX até a década de 40 do século seguinte. Um artigo no jornal $A$ Opiniáo, ano I, no 2, de 14 de novembro de 1902, publicado em São Vicente, comentou o seguinte:

[...] é impossível descrever o espantoso quadro de miséria que se nos deparou ali. Figuras esquálidas, aos montóes, estiradas no chão das infectas espeluncas, 
abrem escancaradamente a boca ressequida pedindo pão, implorando socorro. Todas aquelas palhotas, acham-se acumuladas de desgraçados, sofrendo cruelmente os horrores da fome. A febre e a disenteria acompanham aqueles horrores, tornando impossível viver naquele ambiente, onde está nitidamente desenhada a figura da morte! Apelando para as almas generosas, esperamos que socorram aqueles infelizes (apud Carreira, 1984:52).

Em 1903, a revista Portugal na África, publicada em Lisboa (v. 10, no 116, p. 477-480), tomou posição sobre a crise:

a crise alimentícia, originada por falta de chuvas, que os modernistas governadores e alguns funcionários que nesta província exercem cargos elevados atribuem à indolência dos seus habitantes, são unicamente devidas à péssima situação geográfica deste arquipélago, em que as nuvens do sul prenhes de água, são na sua marcha para o norte repelidas pelos ventos do norte. Há abundância de chuvas quando os ventos do sul predominam aos do norte. [...] Há de notar ainda a desarborizaçáo que estas ilhas, nomeadamente a de Santiago, vão sofrendo anualmente sobretudo nas épocas de crise, em que o povo, torturado pela necessidade e miséria e abandonado dos poderes públicos, lança mão da lenha como único recurso para matar a fome (apud Carreira, 1984:56-57).

Mas as crises continuavam a assolar o país naquele início de século. Os anos 1920 apresentaram inúmeros relatos como este, sobre a Ilha do Fogo em 1926, que descreve cenas de grande tristeza:

a vila estivera quase que permanentemente invadida de ondas de famintos procedentes do interior, que deambulavam de rua em rua à busca de quaisquer alimentos. [...] Não eram só as lamentaçóes em coro que atormentavam as pessoas. $\mathrm{O}$ cheiro nauseabundo de corpos que não se lavavam há semanas ou meses, as úlceras malcheirosas e os farrapos de que se cobriam, tudo constituía um quadro trágico de miséria (apud Carreira, 1984:91).

Foi assim que o autor chegou às duas mais catastróficas crises no século XX: as de 1941-1943 e 1947-1948. Essas crises não se distribuíram uniformemente, uma vez que suas causas foram as mais diversas: além da falta de chuvas, influíram a situação internacional, a decadência comercial do porto de São Vicente, as perturbaçôes no comércio externo, as dificuldades de circulação do correio internacional e a consequente falta de remessas dos emigrados etc. Com tudo isso, fica o registro de que em meio século, aproximadamente, a população de Cabo Verde foi martirizada por sucessivas calamidades que, sem dúvida, marcaram não só os que viveram esse período e sobreviveram a ele, mas também as geraçóes seguintes. ${ }^{?}$ 
Inseridos nessa realidade, os escritores e membros do movimento claridoso apropriaram-se com destaque do meio ambiente do arquipélago em seu discurso, constituindo-o como um fator central na construção da personalidade do homem cabo-verdiano. O que percebemos na análise dos textos publicados na revista Claridade é que se adotou um discurso determinista na construção da especificidade cabo-verdiana. Conforme esse discurso, a personalidade do homem das ilhas era condicionada por fatores de ordem climática e geográfica, e a participação do meio ambiente na formação da idiossincrasia crioula era central.

Os claridosos debruçaram-se sobre Cabo Verde, sobre o drama do povo nessa terra esquecida pelo Senhor, onde os homens lutavam diariamente contra uma natureza madrasta. Conforme afirma Germano Almeida (2010), o drama reside na penosa constatação de que a natureza é, em Cabo Verde, tão rebelde e diabólica que o homem náo consegue vencê-la; o homem, antes de tudo, é vítima dela. A seca assume a centralidade na formação da personalidade do habitante das ilhas. É o homem cabo-verdiano descrito como um homem "resignado", uma vez que "a natureza ingrata [...] lhe tira as qualidades mais apreciadas no mundo pragmático de hoje” (Augusto, 1986:4).

O quadro em que se inserem essas obras é o seguinte: a questão passou a ser a construção da literatura como plataforma onde pudessem ecoar as necessidades do "povo" e o poeta transformou-se em porta-voz dos desesperos. Instituir-se como porta-voz do "povo" constituiu-se, a partir daí, na forma de realizaçáo literária do intelectual cabo-verdiano. Ele se realiza como tal, ao espelhar na literatura as circunstâncias concretas que pode observar. A fórmula básica dessa produção literária seria "o real é dramático e o dramático é estético literário". Segundo Manuel Lopes (1986), o neo-realismo cabo-verdiano se definiria pela ausência de ideologia. A seca seria "uma realidade histórica, uma fatalidade geográfica” que dispensa ideologia, só precisa ser descrita de forma realista. Para demonstrar que seus romances atingiam esse objetivo, argumentavam que a realidade cabo-verdiana contrastava de tal forma desgraça e festa que isso se expressava naturalmente de forma estética, portanto literária. É como se o estético já estivesse incorporado ao real, bastando ao artista expô-lo.

$\mathrm{Na}$ pretensão de fazer uma observaçáo simples e isenta de ideologia e de reproduzir fielmente a realidade, a literatura propiciaria testemunhos sociológicos. Buscando uma literatura realista e transparente, esse grupo participava da produção da realidade social, como lugar de definição política de uma identidade cabo-verdiana. $\mathrm{O}$ engajamento dos escritores num investimento político se dava na medida em que, embora se pretendendo isento, o neo-realismo cabo-verdiano carregava uma utopia: "futuro prometedor, sem fome, sem mortandade maciça, 
sem escravidão, sem injustiça social" (Lopes, 1986) — o oposto da realidade que descreviam e denunciavam.

O poema "Casebre", de Jorge Barbosa (1956), tem o poder de nos invadir com a triste realidade que assolava o Cabo Verde colonial, denunciado em verso e prosa pelos claridosos:

Foi a estiagem/E o silêncio depois/Nem sinal de planta/nem restos de árvore/ no cenário ressequido da planície/[...]/Foi a estiagem que passou./Nesses tempos/não tem descanso/a padiola mortuária da regedoria./Levou primeiro/o corpo mirrado da mulher/com o filho nu ao lado/de barriga inchada/que se diria/que foi de fartura que morreu./O homem depois/com os olhos parados/ abertos ainda./Tâo silenciosa a tragédia das secas nestas ilhas!/Nem gritos nem alarme/— somente o jeito passivo de morrer!/[...].

Nascia, portanto, o cabo-verdiano como um "homem apesar da seca", aquele que guardava uma relação estranha com o destino e até mesmo com Deus. Como expresso no poema que abriu esta seção, como resultado de um acaso nasceram as ilhas esquecidas pelo Senhor, fato determinante no destino de seu povo. Deus não deu riquezas a Cabo Verde, os cabo-verdianos seriam como filhos bastardos que souberam criar suas terras e sobreviver a elas, por isso seriam eles a sua única riqueza. Assim surgiu o cabo-verdiano como herói, como aquele que sobreviveu a uma terra onde não há condiçôes de vida. ${ }^{10}$

O movimento que se formou ao redor da revista Claridade afirma ter atingido o apogeu na reivindicação dos valores locais e ter tomado para si a voz que, até então, era quase exclusiva dos colonizadores. Essa virada consistiu na procura de temas do dia a dia, do drama do homem das ilhas, do universo da seca, das fomes, da insularidade, da aridez e da emigração, e na afirmação de uma identidade heroica tecida com base nas condiçóes impostas pela geografia e pelo clima. Entretanto, essa identidade é marcada tanto por contrastes quanto por continuidades. $\mathrm{Ou}$ seja, pela análise cuidadosa do discurso literário dos claridosos, podemos perceber como esses atores selecionaram e adaptaram os discursos sobre Cabo Verde à própria necessidade de criar uma nação autônoma e descolonizada, ao mesmo tempo que mantinham os valores portugueses e construíam um distanciamento do continente africano.

Observa-se, então, uma importante relação de continuidade e descontinuidade com os discursos analisados na primeira seção. No que se refere à determinação do ambiente na configuraçáo cultural em formação, percebemos continuidades. Porém, estas se quebram quando se analisa que tipo de homem emergiu dessa relação com o meio; a qualidade desse homem muda essencialmente. Retomando a perspectiva dos colonizadores, viajantes e missionários, estes vendo a pobreza 
da terra diretamente associada à pobreza e indolência dos nativos, temos alguns paralelos. Náo só a terra era descrita de maneira negativa, mas os homens que nela trabalhavam e que dela viviam eram incorporados nessa visão da paisagem. Agora, a natureza se apresenta como "ingrata"; o solo, como "agressivo"; a paisagem, como "trágica". Porém, o homem cabo-verdiano é oposto a esse quadro; mais do que isso, é sua face positiva que se apresenta nas afirmaçôes de "doçura da população", de um "povo heroico", um povo que luta incansavelmente contra o destino de viver numa natureza ingrata.

As caracterizaçóes sobre a paisagem e seu lugar na vida do cabo-verdiano tomaram um lugar central num movimento de definição de uma identidade própria realizado pelos claridosos. Dessa forma, o novo discurso inverteu a relação entre natureza e cultura estabelecida pelos colonizadores. A ideologia que imperou no discurso da Claridade foi a do "cabo-verdiano apesar da seca", vítima das dinâmicas climáticas e do imponderável geográfico. Entretanto, essa mesma natureza, embora descrita e caracterizada muito mais em seus aspectos negativos, por vezes seria exaltada. A desgraça da mãe-terra residia em não poder alimentar seus filhos, ou seja, em não poder cumprir a função que Deus lhe confiou. Porém, quando a chuva caía e a paisagem tornava-se verde e produtiva, passava a ser caracterizada como bela e abençoada, continuando a admiração pelos campos verdes e férteis, associando beleza e fertilidade. ${ }^{11}$

A grande mudança com relação aos séculos anteriores reside na forma como se caracterizou o homem fazendo parte dessa paisagem. O discurso claridoso negou a imagem do homem indolente e, em certa medida, culpado pela improdutividade da terra e o colocou no lugar de vítima, aquele que sofria com o "destino" de viver numa terra ingrata. Porém, pela sua índole, que nega a passividade, o homem cabo-verdiano dos claridosos superou esse destino, resistiu à ingratidão do clima e, em uma relaçáo de ódio e amor, tirou da terra aquilo de que necessitava para sobreviver. O cabo-verdiano resiste ao clima, é aquele que sabe esperar a chuva cair e, quando ela cai, extrair da terra o alimento — daí sua heroicidade. Se, por um lado, as condiçôes de aridez, "ingratidão" e "agressividade" da paisagem descrita por esses atores eram tidas como entrave ao desenvolvimento e à plenitude do cabo-verdiano, por outro lado, a terra era mãe, provedora.

Em uma busca constante por refletir a realidade das ilhas, os claridosos ambicionaram expor alguns pressupostos que fundamentavam as percepçóes dos cabo-verdianos da primeira metade do século XX sobre a terra, a aridez e a paisagem. Ao explorar essa relação, o que estava em jogo era a formação de um sentimento de nação e de uma identidade, ambas sintetizadas na noção de caboverdianidade construída nesse emaranhado: o pensar a terra e o pensar a 
si mesmo. Nesse processo, a natureza foi incorporada como sujeito humanizado, expressa na ideia de mãe-terra, na relação com a chuva e na importância do milho como símbolos-chave na formação da identidade desse povo.

A força da poesia e da ficção da Claridade e sua influência em várias esferas da vida do arquipélago encontram-se na disseminação de sua ideologia. A caracterização de grandeza, heroísmo e resistência desse povo "abandonado por Deus nesses dez grãozinhos de terra perdidos no Atlântico" é incorporada ainda hoje na autocaracterização do cabo-verdiano, como um elemento que define sua identidade seja no cotidiano, seja na esfera política. A sociedade e, também, sua relação com a natureza foi dramatizada, inventada e reinventada pela poesia e pela literatura da época. A eficácia dessa construção é vivida dentro de um processo que, apesar de polêmico, é atualizado pelo Estado e pela população na constante busca por uma especificidade cabo-verdiana.

\section{“A reconquista da natureza": o Estado moderno e o meio ambiente}

Dispersas, emersas, sozinhas sobre o Oceano

Sequiosas, rochosas, pedaços do Africano, do negro continente, as enjeitadas filhas, nossas ilhas, navegam tristemente ... Qual naus da antiguidade, qual naus do velho Portugal, aquelas que as entradas do imenso mar abriram ... As naus que as nossas descobriram. Ao vento, à tempestade, navegam de Cabo Verde as ilhas, as filhas do ingente e negro continente ...
São dez as caravelas em busca do Infinito ...

São dez as caravelas, sem velas, em busca do Infinito ... A tempestade e ao vento, caminham ... navegam mansamente as ilhas, as filhas do negro continente ... — Onde ides naus da Fome, da Morna, do Sonho, e da Desgraça?... — Onde ides? ... Sem rumo e sem ter fito, sozinhas, dispersas, emersas, nós vamos, sonhando, sofrendo, em busca do Infinito! ...

(Amilcar Cabral, Naus sem rumo) $^{12}$ 
Com a proclamação da Independência Nacional, em 1975, deu-se um passo decisivo no sentido de criar condições políticas e, aos olhos dos próprios caboverdianos, renovaram-se as esperanças de novos tempos, de novas chuvas caindo em um chão mais adubado e prometendo colheita mais rica e abundante. Nos documentos oficiais do Estado recém-independente, a natureza era um sujeito de destaque, um desafio a ser superado. $\mathrm{O}$ ambiente continuava sendo percebido como hostil e a seca vinha sendo agravada pela desertificação crescente em cinco séculos de ocupação e por um crescimento demográfico não condizente com a evoluçáo dos recursos. A insularidade era mais um fator a ultrapassar na busca por um projeto mobilizador para a construção do Estado com unidade nacional. Para combater tal quadro, tornava-se central uma política de "reconquista da natureza" (Lesourd, 1995) ligada a razóes políticas, culturais e econômicas. O que estava em jogo era a reconstrução, prática e simbólica, do lugar da natureza nessa sociedade, na tentativa de "apagar e suavizar séculos de exploração e de 'mau uso' da terra e de se construir como nação moderna” (1995: 07).

A estratégia de Cabo Verde para sua inserção no contexto global foi a de se distinguir de outros países pobres com o intuito de atrair capital para si e entrar numa posição diferenciada no espaço econômico global. Devido a um contexto politicamente favorável no pós-independência, Cabo Verde passou a responder às expectativas de parceiros internacionais, adotando a linguagem do planejamento como via adequada para o combate à pobreza, um de seus maiores desafios. Como afirma Robertson (1984), a adaptação a um discurso de planejamento nesses países pobres produziu uma crescente atração das intervenções econômicas e políticas dos países ricos estrangeiros, que, desde o período pós-guerra, seguiram o exemplo americano e estabeleceram programas de ajuda internacional a países da África, à Índia etc. É nesse contexto de inserçấo na economia mundial em busca de atrair programas de auxílio político, social e econômico que estão os Planos Nacionais de Desenvolvimento (PNDs): planos de escala nacional que se vinculam à gestão estratégica do território e que funcionam como um dos instrumentos utilizados pelo Estado para o planejamento de suas metas.

Como veremos, as políticas adotadas pelo governo local buscavam uma conformidade com as concepçóes de modernidade que imperavam no cenário mundial. Assim, os planos e projetos de açóes de desenvolvimento podem ser vistos como formas de modulação, apropriação e gestão do espaço e da população que apresentam continuidades por se encontrarem inseridos num mesmo paradigma desenvolvimentista. Entre 1982 e 2000, foram elaborados quatro Planos Nacionais de Desenvolvimento para Cabo Verde. Embora correndo os riscos de simplificação, se me é permitido resumir os objetivos desses documentos 
oficiais, temos como principais pontos: uma preocupação em atingir e assegurar um nível de crescimento econômico, a construção de uma sociedade desenvolvida, o estabelecimento de bases para a integração nacional e a promoção de meios para a utilização dos recursos humanos e das dimensóes físicas e climáticas do território nacional. Entre estes, um elemento merece destaque: a luta contra a pobreza em um país de fracos recursos naturais.

No que diz respeito à pressão sobre os recursos naturais, a pobreza e o baixo nível de vida da população foram apresentados como um importante fator de degradação ambiental que, associado à carência dos recursos disponíveis, levaria a população à exploraçáo exagerada e à degradação completa dos meios de sobrevivência existentes nas ilhas. Junte-se ainda o mau aproveitamento de alguns recursos naturais locais (os recursos marinhos, por exemplo) e uma concentraçáo excessiva em torno dos recursos agro-silvo-pastoris. A natureza das ilhas e a pobreza dos homens reapareceu, então, como um duplo que teimava em se entrelaçar e se confundir nas narrativas sobre o arquipélago. Em uma nova roupagem, o homem das ilhas não seria mais o nativo indolente e preguiçoso que não sabe retirar da terra os seus frutos, nem tampouco o herói claridoso que resiste às agruras do clima.

No Cabo Verde independente, o discurso desenvolvimentista já não acusava os pobres por sua irracionalidade com relação à paisagem, mas por sua falta de consciência ambiental. Aquelas representaçóes das gentes pobres e de pele escura destruindo a vegetaçáo, desmatando desordenadamente, sendo indolentes com relação à paisagem só aparecem aqui como uma referência a um passado que deve ser convertido, por isso a necessidade da educação ambiental e de programas nesse âmbito. Por outro lado, náo se incorporou aquela visão romântica dos literatos do início do século XX, do cabo-verdiano herói aposto à paisagem ingrata. A ligação entre pobreza física e humana foi estabelecida de maneira direta nos documentos, porém no sentido de que a pressão exercida pelos homens se devia à falta de informação, o que poderia ser revertido com a adoção de políticas ambientais de formação e informação.

Foi nesse contexto que, paralelamente à formulação e implementaçáo do Programa Nacional de Luta contra a Pobreza (que, com apoio de fundos internacionais, se estendeu até meados dos anos 2000), foram traçadas as diretrizes para o estabelecimento das políticas de proteção ambiental. A pobreza social e a natural foram tidas como faces de uma mesma realidade que deveriam ser combatidas em conjunto, sendo a conservação do meio ambiente uma ferramenta de desenvolvimento social - estão aí as bases para a noção de desenvolvimento sustentável. Foi na busca de filiar-se a esse moderno conceito 
de desenvolvimento, já tão difundido em outros países, e de contribuir para os objetivos lançados desde o primeiro PND que começaram a ser estabelecidas as prioridades em conservação da natureza no país.

A problemática do meio ambiente e da paisagem hostil de Cabo Verde ganhou espaço e diversos documentos foram elaborados no âmbito de projetos governamentais em parceria e com financiamento de organismos internacionais como FAO, Banco Mundial e ONU. A preocupação comum dos estudos era com a problemática do clima, da erosão e da desertificação em Cabo Verde, de sua inserção na zona do Sahel, numa procura de desmitificar concepçóes errôneas a respeito da paisagem das ilhas. Tentando reverter a concepção de que "Cabo Verde foi abandonado por Deus", ou de que "a seca é um castigo divino", tâo presente no discurso dos poetas e introjetado no pensamento local, os documentos técnicos buscavam apresentar os fatores ecológicos e políticos que faziam com que a paisagem cabo-verdiana fosse encarada historicamente como um dos fatores mais negativos do país.

$\mathrm{Na}$ condição de um país inserido geograficamente na zona do Sahel, Cabo Verde confronta-se com um clima sujeito a secas frequentes, com grandes repercussóes na produção de alimentos. Apesar de localizado no oceano, as características climáticas, nomeadamente a duração da estação úmida, a irregularidade das precipitaçóes e a frequência dos ventos quentes e secos colocam o arquipélago no conjunto da regiáo saheliana. A esses fatores associam-se outros, de natureza diversa e característica de um espaço insular: a escassez do solo e da água, o acentuado relevo, a dispersão geográfica e a pequenez do território. Diante de todos esses fatores, o homem, principalmente o do campo, vê-se obrigado a agir de forma imediatista em sua luta pela sobrevivência, exercendo pressão sobre os recursos naturais e realizando uma má gestão do solo e da cobertura vegetal, atividade antrópica considerada como possível causa da incidência da desertificação; e assim surge um círculo vicioso em que a seca alimenta a seca (Cruz \& Semedo, 1991).

Segundo essa tese, diante da seca, o homem é forçado a intensificar sua relação de exploração com o ambiente por meio de diversos ajustes de comportamento, aumentando a destruição da cobertura vegetal e agravando os problemas de erosão, tempestades de poeira e concentração de poluentes na água, que por sua vez induzem efeitos nocivos sobre a saúde pública, a vida silvestre e a qualidade da paisagem. O que se procura evidenciar é que, de acordo com os registros climáticos de pelo menos um século, a seca é uma característica do clima de Cabo Verde e, dessa forma, qualquer estratégia visando a um período úmido no futuro não passa de quimera — daí a ideia de que as estratégias de desenvolvimento do 
país devem alicerçar-se no princípio de que a seca é uma constante e os caboverdianos devem aprender a viver e conviver com ela.

A partir da constatação técnica da questão da paisagem e do clima em Cabo Verde, os mesmos estudos apresentaram projetos, alguns já desenvolvidos e outros por desenvolver, que visam a uma melhoria no aproveitamento do solo e do clima no arquipélago. O que se verifica é uma tentativa de reverter o processo de encarar a paisagem local como negativa, como um entrave ao desenvolvimento, e adotar uma nova relação com esse meio a fim de melhor aproveitar as características geográficas e climáticas do país em favor da melhoria de vida da população local. O primeiro passo foi dado logo após a independência, em 1975, com a implementação do Programa de Reflorestamento nas principais ilhas agrícolas; em continuidade, seguiu-se o Programa de Ação Nacional de Luta contra a Desertificação e de Mitigação dos Efeitos da Seca (PAN) e, nos anos 1990, o Plano de Ação sobre a Biodiversidade. Esses são os principais programas implementados pelo governo cabo-verdiano em conformidade e em parceria com programas de organismos internacionais europeus implementados em outros países, principalmente no continente africano. ${ }^{13}$

Além disso, tais programas têm se dedicado à construção de uma "nova relaçáo com o meio ambiente" das ilhas. Ao longo dos anos 1990, o Secretariado para o Meio Ambiente (SEPA) publicou a FOLHA, um informativo periódico bimensal. Em sua primeira edição, lançada em 17 de junho de 1995, dia mundial da luta contra a desertificação, foi definida a meta do informativo de ser mais um instrumento a serviço dos cabo-verdianos na tarefa de sensibilização para os problemas do ambiente e, mais especificamente, na luta contra a desertificação. Apresentou-se de forma clara uma tentativa de mudança de foco no que diz respeito à relaçáo considerada ideal entre o homem e o meio ambiente, no sentido de sensibilizar os cabo-verdianos sobre a necessidade do combate à desertificação e da proteção ambiental. Essa mudança de perspectiva já era sentida nos documentos apresentados pelos técnicos, a diferença agora é que o sujeito a ser atingido é a população; a discussão volta-se não somente para os órgãos ou as agências de financiamento internacionais, mas para os cabo-verdianos em geral.

Erros foram cometidos no passado, no tocante aos aspectos em referências, os quais em conjunto com as condições climáticas prevalecentes na região onde nos inserimos, muito contribuíram para a degradação dos fracos recursos com que a natureza nos dotou. Face a estas circunstâncias, não a devemos culpar pela sua ausência de prodigalidade na concessão de recursos, e muito menos lamentar os erros praticados no passado pois foram fruto do desconhecimento dos mecanismos que regem as leis do universo e um imperativo da luta pela 
sobrevivência. Estes erros devem, antes, constituir motivo de profunda meditação, na procura de soluçôes para sua correção, para assim criarmos sólidas condiçóes para um desenvolvimento harmonioso e fundamentalmente sustentável. O amor do homem cabo-verdiano pela terra onde nasceu e/ou que foi berço dos seus antepassados, impulsiona-o no sentido de conhecer as condiçóes específicas da terra natal e assim agir em consequência, na busca das soluçốes mais adequadas para o seu desenvolvimento (SEPA, 1995a:1).

O trabalho realizado pelo SEPA e publicado periodicamente nesse informativo visava exatamente educar, sensibilizar, informar e convocar a população para uma mudança de atitude com relação ao ambiente. $\mathrm{O}$ discurso era o de que, embora Cabo Verde fosse árido e desarborizado, se a população e o governo adotassem uma nova postura, esse quadro historicamente negativo e penoso poderia ser revertido em favor dos cabo-verdianos e do desenvolvimento econômico do país. "Combater a desertificação é promover o desenvolvimento econômico e social, é eliminar a pobreza, é implantar a justiça social que conduz ao bem-estar das populaçôes" (SEPA, 1995b:2). Conceitos como o de desenvolvimento e ambiente eram vistos como interdependentes, e a integração da gestão e da conservação dos recursos passou a constituir a base do desenvolvimento durável. A restituição e a preservação do equilíbrio ecológico apresentavam-se, em Cabo Verde, como um componente vital de sobrevivência.

Mas há, ainda, outra face a ser explorada nos discursos do nascente Estadonação, a conversão dos atributos naturais negativos em estratégias de atração de ajuda internacional. Ao observar os documentos oficiais dos primeiros anos pós-independência, vemos que, paralela ou contrariamente a um discurso que traduzia uma tentativa de construção do país à luz de modelos internacionais, as características físicas do território eram apresentadas como um entrave ao desenvolvimento. Estrategicamente, os atributos negativos convertiam-se em valor, com potencial de ser explorado na demanda por ajuda internacional.

Trajano Filho (2000) analisa esse mesmo aspecto ao falar da Guiné, que se apresenta em suas características negativas diante do "outro" como uma "pobre" pátria que necessita ser incorporada e auxiliada pelo sistema internacional, caso contrário permaneceria num estado de penúria. Tanto na apresentação de documentos técnicos quanto no discurso da elite local, as características observadas por Trajano Filho no contexto da Guiné são válidas também para Cabo Verde. A afirmação de que este é pobre, seco e sem recursos faz parte do repertório de expressóes usado para "mobilizar a população na luta pelo desenvolvimento, para demandar ajuda internacional e até para explicar o mau uso desta ajuda" (Trajano Filho, 2000:19). 
Apesar de novas tendências de otimização das capacidades paisagísticas do país, é fato que as práticas tradicionais e as concepções históricas de que a natureza é hostil continuam a imperar na caracterização local. Nesse sentido, apoio-me no argumento de Trajano Filho (2000), ao tratar do contexto colonial português, de que a percepção de uma carência difusa e a autorrepresentaçáo marcada pela fragilidade funcionaram, e funcionam ainda hoje, para superar as limitaçóes objetivas do Estado cabo-verdiano nos planos político e econômico desde o início do século, justificando e legitimando a necessidade de recursos e investimentos externos para que os cabo-verdianos pobres e fracos de recursos naturais, mas corajosos e portadores de um discurso desenvolvimentista moderno, mantivessem a atração e o interesse da ajuda internacional.

$\mathrm{Na}$ verdade, o mesmo autor focaliza o caso cabo-verdiano afirmando que, nesse país, a autoimagem insular era marcada por uma espécie de fragilidade irrevogável, por ser produto do meio físico e social. Meu argumento é o de que, no período pós-independência, essa autoimagem de fragilidade é incorporada pelo Estado para "vender" e justificar a posição de Cabo Verde no mercado mundial. Por trás de um discurso histórico herdado da situação colonial de que "somos pequenos, coitados, frágeis em termos de recursos naturais, não temos nada” — e em consonância com um discurso moderno de que, apesar disso, "somos honrados e estamos em busca de um desenvolvimento sustentável, nos preocupamos com a preservação do meio ambiente, realizamos políticas ambientais" -, o Estado cabo-verdiano atraiu uma série de investimentos dos programas de ajuda externa aos países carenciados, bem como conquistou seu lugar, ainda que periférico, na economia mundial: o de um país pequeno, mas honrado (Trajano Filho, 2000).

\section{Consideraçóes finais}

A noção de destino é frequentemente acionada em verso e prosa para definir o cabo-verdiano. São inúmeras as versôes que esse destino assume na cultura popular produzida no e sobre o arquipélago. Emigração, partida, regresso, mar, saudade, fome, seca, luta, insularidade, sofrimento, resignação são atributos de um povo que tem a sorte atrelada à sua condição geográfica. Para Jorge Barbosa, o destino se cumpriu quando o descobridor chegou, saltou da proa e enterrou seu pé direito na areia molhada. Para Baltasar Lopes, o destino foi traçado por Deus, que, sem se aperceber, criou as dez ilhas perdidas no Atlântico. Para Amilcar Cabral, as ilhas são como naus perdidas do continente negro que, enjeitadas por este, navegam tristemente perdidas pelo oceano.

A certeza de um destino a se cumprir associada ao pertencimento a um espaço que, apesar de pequeno, hostil e perdido, foi dado por Deus, parece informar 
o processo pelo qual os cabo-verdianos constituem sua identidade, o sentido de si mesmos e sua ligação à terra natal. Meu esforço aqui foi o de mapear as concepçôes da terra e da paisagem em Cabo Verde, na medida em que elas podem estar ligadas ao processo histórico de construçáo desse país; meu ponto de partida foi o da paisagem experienciada ao longo da história, seja nas políticas coloniais e governamentais, seja na literatura ou no dia a dia. Centralizando na identidade, a concepção dos cabo-verdianos sobre as ilhas tem profundas implicaçóes na cultura, política e economia, e transforma a natureza em um processo cognitivo.

O processo de colonização, que nomeou e construiu Cabo Verde e também os cabo-verdianos, posicionou-os de maneira periférica e silenciosa nos relatos dos viajantes e missionários, num primeiro momento; e destrutiva e negativa, nos dois últimos séculos aqui apresentados. Começamos a delinear, assim, a hipótese da construção da paisagem como um processo no qual o sujeito que domina o discurso, o colonizador, se apropria da natureza e a transforma em função de seus interesses e concepçóes, sendo a produção da paisagem uma ação estratégica e sistemática.

Porém, a continuidade da análise nos permite ultrapassar a simples reprodução da dinâmica de posse e inocência inerente ao processo colonial. Trazer os discursos dos claridosos e dos documentos oficiais do período pós-independência é um esforço nessa direção, de demonstrar a dinâmica da autorrepresentação, tanto no contexto da resistência colonial quanto na construção da nação emergente e das (re)classificações que daí surgem. No caso da construção da paisagem, como nas demais esferas culturais, não há relação absoluta, mas constantemente feita e refeita de acordo com a época, as concepçóes vigentes e os interesses, numa dialética que atravessa o passado e chega até o presente.

Se, por um lado, a natureza é uma ordem e um processo que náo criamos, e que continuará a existir na nossa ausência, por outro, é também uma criação das nossas mentes. Por mais que nos esforcemos para ver o que ela é objetivamente, em si mesma, por si mesma e para si mesma, em grande medida caímos presos nas grades da nossa consciência e de nossas redes de significados. Daí a opção por estudar a paisagem, as percepçóes e os valores que as pessoas refletem sobre o mundo não humano - o pensamento sobre a natureza e sua construção como um processo. Se a dinâmica das forças produtivas imposta por um império colonial a uma determinada porção da natureza a modifica, essa percepção é reconfigurada no processo de criação da moderna nação independente. Pela análise das construçôes sobre a natureza do arquipélago, é possível acompanhar as dinâmicas não só das relaçôes sociais, políticas e econômicas, mas também entre os dois níveis, o natural e o cultural. 
Para mim Cabo Verde é simplesmente isso, dez ilhas de um povo que quer ser mais do que aquilo que o destino e a natureza o propiciou

(Dr. Jorge Figueiredo — Entrevista)

Recebido em 24/09/2015.

Aceito em 21/10/2015.

Andréa Lobo é doutora em antropologia social. Atualmente, é professora da Universidade de Brasília e pesquisadora e coordenadora do Laboratório de Estudos em Etnologia em Contextos Africanos (ECOA). Realiza pesquisa em Cabo Verde desde o final da década de 1990. É autora do livro Tão longe, tão perto: familias e movimentos na ilha de Boa Vista de Cabo Verde, publicado pela Editora da Uni-CV. Organizou as coletâneas África em movimento (com Juliana Braz Dias) e Entre fluxos, e escreveu diversos artigos sobre a sociedade cabo-verdiana. Seus interesses de pesquisa são: dinâmicas familiares, migraçóes, fluxos globais e identidade. Contato: andreaslobo@yahoo.com.br

\section{Notas}

1. O material etnográfico aqui apresentado foi coletado durante pesquisa documental realizada na capital, Cidade da Praia, no Arquivo Histórico de Cabo Verde, em instituiçôes governamentais e organizações não governamentais, sendo complementado com entrevistas a técnicos dessas instituições. Tais dados já foram objeto de minha reflexão em outros momentos (Lobo, 2001, 2012). A presente análise aprofunda reflexôes sobre as dinâmicas de classificação e de construção da paisagem no período de colonização e suas consequências, continuidades e descontinuidades na construção do que é hoje Cabo Verde.

2. Como bem lembra Trajano Filho (2010:9), o tropo "imagine-se o leitor sozinho ... numa praia tropical próxima a uma aldeia nativa” (Malinowski, 1976:23) é um exemplo de como a ideia de paisagem tem aparecido de maneira furtiva nos textos etnográficos como um instrumento retórico importante desde Malinowski.

3. Viajante genovês a quem se atribui o status oficial de descobridor das ilhas de Cabo Verde.

4. A diferença entre estes e os outros agentes que comerciavam anteriormente foi que ocorreu uma diminuição daquela inicial liberdade de ação no comércio por parte 
do governo português com relação aos moradores de Santiago, sendo estabelecida uma série de medidas que lhes acarretava graves prejuízos. Para sobreviverem, não restava alternativa senão a de desobedecer às determinaçōes régias em tudo que dissesse respeito às leis do comércio. A reação contra todas essas leis não tardou a surgir, com a formação de grupos de delinquentes cuja atividade concorreu, no decurso do tempo, para a rápida desagregação do tráfico português na costa africana.

5. Para salientar meu argumento de que os relatos iniciais são mais "construçôes ideais" do que descriçóes do que foi visto, lembro ao leitor do desinteresse inicial pelo arquipélago, que postergou por alguns anos a sua efetiva ocupação.

6. Observo a continuidade da comparaçáo da colônia com o reino. O espanto e o estranhamento com o novo são recorrentes, bem como a necessidade de se remeter ao familiar. Esse ato de reconhecimento por intermédio da comparação e da nominação parece confortar o espírito do explorador diante do desconhecido, que é transformado quase em um familiar imaginado (Baêta Neves, 1978; Pagden, 1983).

7. Segundo Silva (1996), as secas só teriam se convertido em fomes com tais impactos nos séculos XVII e XVIII, porque, a partir dessa época, Santiago não podia mais importar alimentos em abundância nem vender seus escravos a preços baixos, e menos ainda voltar a adquirir escravos, passadas as crises.

8. É preciso sinalizar aqui que há um conjunto de controvérsias em torno do movimento. Dos Anjos (2002), por exemplo, é um dos autores que reflete criticamente sobre a positividade e a centralidade atribuída aos claridosos no Cabo Verde atual. Em sua análise sobre intelectuais, literatura e poder em Cabo Verde, o autor detalha o universo de disputas e um processo posterior à independência que, em sua perspectiva, teria apagado ambiguidades, dilemas e problemas deste e de outros movimentos (o da Revista Certeza, por exemplo) em nome da construção de uma nação que, na construçáo claridosa de uma caboverdianidade, teria virado as costas para a África em marcada continuidade com o sistema colonial. Sobre esse debate, ver Dos Anjos (2002, 2003) e Furtado (2013).

9. Fica a pergunta sobre a falta de articulação e de açáo por parte da metrópole com relação a táo frequentes crises. $\mathrm{O}$ que os documentos sinalizam é que, na maioria das vezes, as autoridades portuguesas não se mostraram preparadas para diminuir os efeitos das crises. Conheciam-se mal as estatísticas das produçóes agrícolas de emergência, assim como as quantidades de alimentos que se deveriam importar. Isso sem falar na descrença de alguns na existência real dessas crises. Oficialmente, a partir de 1950, não foi mais registrada nenhuma grande mortandade pela fome em Cabo Verde. Nos anos 1960, após a elaboração de um relatório sobre o estado das ilhas, o governo colonial passou a encarar com maior interesse os períodos de estiagens, prevenindo-se de meios eventualmente necessários à prestação de apoios bem organizados: missóes de combate às endemias e campanhas de desinfestação nos meios rurais para a erradicação de pragas; 
missão de prospecção de águas subterrâneas que iniciou a perfuração de solos a fim de detectar lençóis de água potável etc.

10. Para além dos números da revista Claridade, os romances Chiquinho, de Baltasar Lopes, publicado originalmente em 1947, e Os flagelados do vento leste, saído em 1959, e Chuva braba, em 1956, ambos de Manuel Lopes, são centrais para o desenvolvimento da perspectiva realista desse movimento político-literário.

11. O frequente trânsito entre os polos positivo e negativo dessa paisagem também é observado no discurso de colonizadores, missionários e viajantes, sendo este também um aspecto que guarda continuidades entre os atores e ao longo do tempo.

12. Poema recolhido em Emergência da poesia em Amílcar Cabral, de Oswaldo Osório (1984).

13. Junte-se a esse processo uma tendência ao desenvolvimento turístico, alternativa que se ampliou com mais efetividade a partir dos anos 2000, figurando como mais uma etapa no estabelecimento da relação entre o homem e a paisagem em Cabo Verde. Sobre essa questão, ver Lobo (2014).

\section{Referências bibliográficas}

ALMEIDA, Germano. 2010. "Cabo Verde: viagem pela história das ilhas". A Semana, 10 ago. 2010.

AUGUSTO, Artur. 1986. "O sentido heroico do mar". Claridade, Revista de Arte e Letras. Praia: Instituto Cabo-verdiano do Livro. (Edição comemorativa do cinquentenário). Publicado originalmente em 1937.

BAÊTA NEVES, Luis Felipe. 1978. O combate dos soldados de Cristo na terra dos papagaios: colonialismo e repressão cultural. Rio de Janeiro: Forense-Universitária.

BARBOSA, Jorge. 1956. Caderno de um ilhéu. Lisboa: Agência Geral do Ultramar.

BRÁSIO, Antônio. 1968. Monumenta missionária africana - África Ocidental (16001622). Lisboa: Agência do Ultramar. (Segunda série, v. IV).

CADAMOSTO, Luis de. 1956. "Navegaçáo primeira de Cadamosto e Usodimare" e "Navegação segunda de Cadamosto e Usodimare". In: Vitorino Magalháes Godinho (org.). Documentos sobre a expansâo portuguesa. Lisboa: Cosmos. (v. III).

CARREIRA, Antônio. 1983. Documentos para a história das ilhas de Cabo Verde e "Rios da Guiné": séculos XVII e XVIII. Lisboa. Mimeo.

1984. Cabo Verde: aspectos sociais. Secas e fomes do século XX. Lisboa: Ulmeiro.

1985. Notícia corográfica e cronológica do bispado de Cabo Verde. Lisboa:

Instituto Caboverdiano do Livro. 
CRUZ, Osvaldo \& SEMEDO, Jorge M. 1991. Consequência do crescimento rápido da população: o caso de Cabo Verde. Cabo Verde: INIA. Mimeo.

DOS ANJOS, José C. 2002. Intelectuais, literatura e poder em Cabo Verde: lutas de definição da identidade nacional. Porto Alegre: NIPC/UFRGS.

. 2003. "Elites intelectuais e a conformação da identidade nacional em Cabo Verde”. Estudos Afro-Asiáticos, 25(3):580-606.

FOSTER, Jeremy. 1996. "Landscape phenomenology and the imagination of a New South Africa on Parktown Ridge". African Studies, 55(2):93-125.

FURTADO, Cláudio. 2013. "Cabo Verde: dilemas étnico-identitários num território fluido”. Ciências Sociais Unisinos, 49(1):2-11.

GOVERNO GERAL DA PROVÍNCIA DE CABO VERDE. 1872. Boletim Official, (43).

HIRSCH, Eric. 2003. "Introduction. Landscape: between place and space". In: Eric Hirsch \& Michael O'Hanlon (eds.). The anthropology of landscape: perspective on place and space. Oxford: Claredon Press. pp. 07-46.

LESOURD, Michel. 1995. État et societé aux îles du Cap-Vert: alternatives pour un petit État insulaire. Paris: Karthala.

LEVINSON, Stephen. 1996. "Language and space". Annual Review of Anthropology, 25:353-382.

LOBO, Andréa. 2001. Seca, chuva e luta: reconstruindo a paisagem em Cabo Verde. Dissertação de Mestrado, Universidade de Brasília.

. 2012. "Do feio ao belo: aridez, seca, 'patrimônio natural' e identidade em Cabo Verde”. In: Lívio Sansone (org.). Memórias da África: patrimônios, museus e políticas das identidades. Salvador: ABA/EDUFBA. pp. 67-90.

. "Em algum lugar da África: turismo e africanidade em Cabo Verde". In: Andréa Lobo, Antonio Motta \& Wilson Trajano Filho (orgs.). A África fora de casa, imagens fora do lugar. Brasília: ABA. 2014.

LOPES, Manuel. 1956. Chuva braba. Lisboa: Caminho.

. 1959. Os flagelados do vento leste. Lisboa: Vega.

. 1986. Claridade, Revista de Artes e Letras. Praia: Instituto Cabo-verdiano do Livro. (Ediçấo comemorativa do cinquentenário).

LOPES DA SILVA, Baltasar. 1947. Chiquinho. Lisboa: África. 
LOVELL, Nadia. 1998. "Introduction". In: (ed.). Locality and belonging. London: Routledge.

MALINOWSKI, Bronislaw. 1976. Argonautas do pacifico ocidental. São Paulo: Abril Cultural. Publicado originalmente em 1922.

MONTEIRO, Adilson. 2013. A Claridade e a assunção da realidade cabo-verdiana: Os Flagelados do Vento Leste, do claridoso Manuel Lopes, entre a fição e a realidade do arquipélago. Dissertação de Mestrado, Universidade Autônoma de Lisboa.

NEUMANN, Roderick. 1995. "Ways of seeing Africa: colonial recasting of African society and landscape in Serengeti National Park". Ecumene, 2(2):149-169.

OSÓRIO, Oswaldo. 1984. Emergência da poesia em Amilcar Cabral. Praia: Dragoeiro.

PAGDEN, Anthony. 1983. The fall of natural man: the American Indian and the origins of comparative ethnology. Cambridge: Cambridge University Press.

ROBERTSON, A. F. 1984. People and the state: an anthropology of planned development. Cambridge: Cambridge University Press.

SECRETARIADO EXECUTIVO PARA O MEIO AMBIENTE (SEPA). $1995 \mathrm{a}$. Folha, 1(1). 1995b. Folha, 1(2).

SILVA, Antônio. L. C. 1996. Histórias de um Sahel Insular. Praia: Spleen.

TRAJANO FILHO, Wilson. 2000. "A constituição de um olhar fragilizado: notas sobre o colonialismo português em África”. Série Antropologia, 408. . 2010. "Introdução". In: . (org.). Lugares, pessoas e grupos: as lógicas de pertencimento em perspectiva internacional. Brasília: ABA.

VALDEZ, Francisco. 1864. África ocidental: notícias e consideraçôes. Tomo I. Lisboa: Imprensa Nacional. 


\section{Resumo}

Este artigo aborda as classificaçóes e percepçóes culturais sobre a paisagem em Cabo Verde no processo de colonização. Nesse sentido, parto do período da descoberta do arquipélago para analisar a visão europeia sobre a paisagem natural da nascente colônia, suas construçóes e formas de classificação sobre o ambiente e as influências dessas representaçôes na formação da sociedade cabo-verdiana duranteos primeirosséculos deocupação portuguesa e, hoje, nas formas como o homem desse país se relaciona com o ambiente físico das ilhas. A análise desse modo particular de representar e se relacionar com a paisagem, bem como do papel que os colonizadores e viajantes europeus desempenharam ao revelar suas impressóes sobre as novas terras, auxiliará na construção de um argumento mais amplo que encara o processo de classificação e domesticação da natureza com consequências profundas, tanto no colonizador quanto no colonizado, e num grau de complexidade que não admite a explicação polarizada nos termos de dominação e resistência.

\section{Abstract}

This article discusses cultural classifications and perceptions regarding landscapes in Cape Verde during the colonization process. In this regard, I start with the period in which the archipelago was discovered to analyze the European view of the natural landscape of the newborn colony, their constructs and forms of classification during the first centuries of Portuguese occupation, and, currently, the manner in which Cape Verdeans relate with the physical environment of the islands. An analysis of this particular manner of representation and relationship with the landscape, as well as the role European colonizers and travelers played upon revealing their impressions about new lands, assist in the construction of a broader argument. According to this argument, the nature classification and the domestication process have profound consequences for both colonizer and colonized, with a degree of complexity that does not admit polarized explanations of domination and resistance.

Keywords: colonization; Cabo Verde; landscape; identity.

Palavras-chave: colonizaçáo; Cabo Verde; paisagem; identidade. 